\title{
ANALISIS BIAS GENDER PADA SOAL UJIAN BAHASA ARAB DI MADRASAH TSANAWIYAH
}

\author{
Sholikah Mi'rotin, Mufidah Cholil \\ Universitas Islam Negeri Maulana Malik Ibrahim Malang \\ email:sholikah.mirotin@gmail.com
}

\begin{abstract}
Gender analysis is not only to determine the equality of public roles between men and women in conversational texts, reading texts in textbooks, but gender analysis can also be carried out on questions used by teachers to evaluate students. For this reason, the author will carry out a gender analysis on the school examination items in Arabic learning which are used to determine student graduation. This study aims to determine the number of questions contained in the gender variant, and whether the school exam questions presented are gender-biased. So that it can be used as evaluation material and can reconstruct evaluations that contain gender bias to become more gender responsive. This research uses a qualitative approach to library research. Data collection techniques using interviews, questionnaires, and documentation. The data analysis technique was carried out in three stages, namely data collection, data presentation and drawing conclusions. The results of the research were: 1) questions containing gender equality consisted of 4 questions, gender neutral consisted of 30 questions, and gender bias consisted of 16 questions. 2) less than half of the school exam questions are gender bias oriented with a percentage of $32 \%$.
\end{abstract}

Keywords: Gender Bias; Evaluation; Test Questions; Arabic Language Learning.

\begin{abstract}
Abstrak
Analisis gender tidak cukup untuk mengetahui adanya kesetaraan peran publik antara laki-laki dan perempuan yang tercantum dalam teks percakapan, teks bacaan yang ada di buku pelajaran saja, namun analisis gender juga dapat dilakukan pada soal-soal yang digunakan guru untuk mengevaluasi siswa. Untuk
\end{abstract}


itu penulis akan melakukan analisis gender pada butir soal ujian madrasah kelas IX pada mata pelajaran bahasa Arab yang digunakan sebagai menentukan kelulusan siswa. Penelitian ini bertujuan untuk mengetahui jumlah soal yang termuat dalam ragam gender, dan apakah soal ujian madrasah yang disajikan berorientasi pada bias gender, sehingga dapat dijadikan sebagai bahan evaluasi dan dapat merekonstruksi evaluasi pembelajaran yang bias gender menjadi lebih responsif gender. Penelitian ini menggunakan pendekatan kualitatif jenis studi pustaka. Teknik pengumpulan data menggunakan wawancara, angket, dan dokumentasi. Teknik analisis data dilakukan dengan tiga tahapan yaitu pengumpulan data, penyajian data dan penarikan kesimpulan. Adapun hasil penelitiannya yaitu: (1) soal yang bermuatan kesetaraan gender terdiri dari 4 soal, netral gender terdiri dari 30 soal, dan bias gender terdiri dari 16 soal. (2) kurang dari setengah soal ujian madrasah berorientasi pada bias gender dengan persentase sebesar $32 \%$.

Kata Kunci: Bias Gender; Evaluasi; Soal Ujian; Pembelajaran Bahasa Arab.

\section{A. Pendahuluan}

Evaluasi merupakan unsur yang sangat penting dalam sistem pembelajaran. Karena evaluasi digunakan untuk mengetahui kemampuan siswa dalam memahami materi yang telah dipelajari. Ridho mengungkapkan bahwa untuk mengetahui seberapa jauh ketercapaian tujuan pembelajaran yang telah direncanakan, dan keberhasilan siswa setelah belajar pada waktu tertentu, maka diperlukan proses evaluasi. ${ }^{1}$ Pernyataan ini juga diperkuat oleh pendapat Miladya bahwa seorang pendidik memerlukan evaluasi guna untuk memperoleh pembelajaran bahasa Arab yang berkualitas. ${ }^{2}$ Sebagaimana yang telah disampaikan oleh Arikunto dan Abdul Jabar bahwa evaluasi adalah aktivitas mengumpulkan informasi yang bertujuan untuk memilih langkah yang tepat ketika mengambil keputusan. Sehingga dengan evaluasi guru dapat membuat sebuah keputusan berdasarkan kriteria yang telah ditetapkan sesuai dengan kemampuan masing-masing siswa. ${ }^{3}$

Dunia pendidikan tidak lepas dari unsur gender. Nilai-nilai gender masuk ke sekolah melalui teks-teks tertulis dalam buku pelajaran, maupun dalam perilaku-perilaku yang mencerminkan nilai dan norma gender yang

\footnotetext{
${ }^{1}$ Ubaid Ridho, "Evaluasi Dalam Pembelajaran Bahasa Arab," An Nabighoh: Jurnal Pendidikan Dan Pembelajaran Bahasa Arab 20, no. 01 (2018): 19-26, https://doi.org/10.32332/an-nabighoh.v20i01.1124.

2 Junda Miladya, “Evaluasi Dalam Pembelajaran Bahasa Arab," Prosiding Konferensi Nasional Bahasa Arab 1, no. 1 (2015), http://prosiding.arabum.com/index.php/konasbara/article/view/21.

${ }^{3}$ Suharsimi Arikunto, Abdul Jabar, dan Cepi Safruddin, Evaluasi Program Pendidikan: Pedoman Teoritis Praktis Bagi Praktisi Pendidikan (Jakarta: Bumi Aksara, 2007), 1.
} 
berlaku dalam kebudayaan masyarakat. ${ }^{4}$ Terkadang guru tidak sadar bahwa materi yang disampaikan kepada siswa merupakan materi yang mengandung bias gender. Sebagian besar guru sudah merasa berlaku adil terhadap siswanya. Namun mereka kurang memperhatikan secara jeli apakah kontenkonten maupun gambar yang ada di buku ajar sudah berwawasan gender atau belum. ${ }^{5}$

Dalam buku-buku pelajaran kita sering menjumpai kalimat-kalimat yang menampilkan bentuk bias gender dengan didominasi oleh budaya patriarki. Budaya patriarki ini mengakibatkan perbedaan perlakuan terhadap siswa yang memiliki jenis kelamin yang berbeda dalam menyampaikan materi. Sebagai contoh dalam buku bahasa Arab tingkat Tsanawiyah, penulis menemukan kalimat-kalimat yang mengandung bias gender. Yang mana kalimat-kalimat tersebut menjadikan laki-laki memiliki peran publik, sedangkan perempuan memiliki peran domestik. Misalnya:

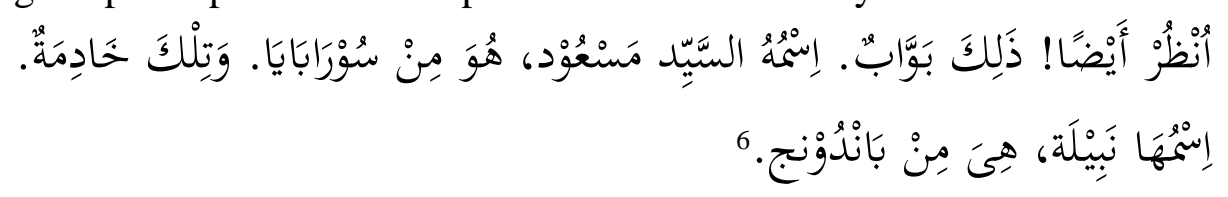

Unzhur aidhan! Dzālika bawwābun. Ismuhu as-sayyidu Mas'ud, huwa min Surabaya. Wa tilka khädimatun. Ismuhā Nabila, hiya min Bandung.

"Lihatlah juga! Itu satpam. Namanya pak Mas'ud, dia dari Surabaya. Dan itu pembantu. Namanya Nabila, dia dari Bandung"

Sebenarnya tidak ada yang salah dalam penggambaran materi pelajaran bahasa Arab tersebut, hanya saja materi yang menjadi bahan sosialisasi formal tidak memberikan penjelasan lebih jauh bahwa pekerjaan satpam bukan hanya dilakukan oleh laki-laki saja, begitu juga dengan peran pembantu bukan hanya dominan dilakukan oleh perempuan. sejalan dengan pendapat Mulyadi bahwa laki-laki dan perempuan mempunyai hak yang sama dalam pekerjaan domestik dan publik. ${ }^{7}$

Jika muatan teks seperti di atas dibiarkan tanpa penjelasan, maka tanpa sadar akan menjadikannya sebagai bahan referensi dalam berkata, bertindak dan membaca kenyataan sosial. Selain itu, gambar (ilustrasi dalam buku)

\footnotetext{
${ }^{4}$ Nur Hasnah, "Bias Gender Dalam Buku Ajar Al-Arabiyah Linnaasyiin," HUMANISMA : Journal of Gender Studies 1, no. 1 (2017): 61-74, https://ejournal.iainbukittinggi.ac.id/index.php/psga/article/view/324.

${ }^{5}$ Michelle Moffatt dkk., Kebijakan dan Anggaran Pendidikan Dasar Responsif Gender 2 (Indonesia Australia Partnership In Basic Education, 2007), 37.

${ }^{6}$ Zaenal Muttaqin, Momon Mujiburrohman, dan Faruq Baharudin, Buku Siswa Bahasa Arab Kelas VII (Jakarta: Kementerian Agama, 2014), 30.

${ }^{7}$ Achmad Mulyadi, "Relasi Laki-Laki Dan Perempuan (Menabrak Tafsir Teks, Menakar Realitas)," Al-Ihkam: Jurnal Hukum Dan Pranata Sosial 7, no. 2 (2014): 247-61, http://ejournal.iainmadura.ac.id/index.php/alihkam/article/view/327.
} 
juga mampu menjadi media yang dapat menanamkan ingatan yang kuat pada siswa. ${ }^{8}$ Semakin mendalam pemahaman siswa tentang teks dan ilustrasi, maka semakin mendalam pemahaman dan ingatan terhadap informasi yang dipelajari. Kalimat yang dibaca dan ilustrasi yang dilihat siswa merupakan pemahaman dasar yang dapat berubah menjadi ideologi dan dapat mempengaruhi opini dan sikap anak. ${ }^{9}$ Sehingga buku ajar memiliki peran penting dalam menyampaikan pesan-pesan kultur, budaya, dan penanaman ideologi terhadap anak. ${ }^{10}$ Inilah yang menurut Shaw (1989) dan Renzetty dan curran (1989) disebut sebagai kurikulum tersembunyi (hidden curriculum) dalam buku-buku teks yang tidak hanya memuat materi formal kurikulum, tetapi juga mengandung materi yang berupa nilai-nilai yang diharapkan tertanam pada diri anak. ${ }^{11}$

Artikel terkait gender bukan pertama kalinya dilakukan oleh peneliti. Adapun artikel-artikel terdahulu yang berkaitan dengan gender dalam pembelajaran bahasa Arab, diantaranya: 1) Nilai Responsif Gender dalam Pembelajaran Bahasa Arab ditulis oleh Rizka Eliyana Maslihah pada jurnal al Mahāra (Jurnal Pendidikan Bahasa Arab), Vol.4, No.2, terbit pada tahun 2018;12 2) Pengembangan Bahan Ajar Modul Bahasa Arab Berperspektif Gender Bagi Siswa Kelas VII Madrasah Tsanawiyah ditulis oleh Irsyad Kholis Fatchurrozaq pada jurnal El-Wasathiya (Jurnal Studi Agama) Vol. 6, no. 2 terbit pada tahun $2018 ;{ }^{13}$ 3) Bias Gender Dalam Buku Pelajaran Bahasa Arab untuk Tingkat Madrasah Tsanawiyah Karya Darsono dan T. Ibrahim ditulis oleh Maulana Khusen pada jurnal Ilmiah Mahasiswa Raushan Fikr,

\footnotetext{
${ }^{8}$ Irsyad Kholis Fatchurrozaq, "Pengembangan Bahan Ajar Modul Bahasa Arab Berperspektif Gender Bagi Siswa Kelas VII Madrasah Tsanawiyah," El-Wasathiya: Jurnal Studi Agama 6, no. 2 (2018): 193-221, http://ejournal.kopertais4.or.id/mataraman/index.php/washatiya/article/view/3553.

${ }_{9}^{9}$ Maulana Khusen, "Bias Gender Dalam Buku Pelajaran Bahasa Arab untuk Tingkat Madrasah Tsanawiyah Karya Darsono dan T. Ibrahim," Jurnal Ilmiah Mahasiswa Raushan Fikr 3, no. 2 (2014): 115, https://doi.org/10.24090/jimrf.v3i2.1023.

${ }^{10}$ Muhammad Jafar Shodiq, "Perspektif Kesetaraan Gender Dalam Buku Bahasa Arab Siswa MTs Pendekatan Saintifik 2013," FENOMENA 8, no. 1 (2016): 01-18, https://doi.org/10.21093/fj.v8i1.302.

${ }^{11}$ Khusen, "Bias Gender Dalam Buku Pelajaran Bahasa Arab untuk Tingkat Madrasah Tsanawiyah Karya Darsono dan T. Ibrahim."

12 Rizka Eliyana Maslihah, “Nilai Responsif Gender Dalam Pembelajaran Bahasa Arab," Al Mahāra: Jurnal Pendidikan Bahasa Arab 4, no. 2 (2018): 181, https://doi.org/10.14421/almahara.2018.042-02.

${ }^{13}$ Fatchurrozaq, "Pengembangan Bahan Ajar Modul Bahasa Arab Berperspektif Gender Bagi Siswa Kelas VII Madrasah Tsanawiyah,” 2018.
} 
Vol. 3, no. 2 terbit pada tahun 2017. ${ }^{14}$ Dan masih banyak lagi artikel yang memuat tentang gender.

Dari beberapa artikel terdahulu, analisis gender dilakukan pada isi materi dalam pelajaran bahasa Arab saja, padahal analisis gender juga dapat dilakukan pada soal-soal yang digunakan guru untuk mengevaluasi siswa pada pembelajaran. Untuk melengkapi artikel terdahulu, penulis akan melakukan analisis gender pada butir soal ujian. Soal ujian yang akan dianalisis merupakan soal ujian madrasah kelas IX pada mata pelajaran bahasa Arab yang digunakan sebagai menentukan kelulusan siswa tingkat tsanawiyah.

Berdasarkan fenomena diatas, maka penelitian ini fokus pada: (1) Berapa jumlah soal yang termuat dalam ragam gender?; (2) Apakah soal ujian madrasah yang disajikan berorientasi pada bias gender? Pembahasan ini dapat dijadikan sebagai bahan evaluasi bagi guru pembuat soal ujian bahasa Arab di masa yang akan datang agar bisa melakukan rekonstruksi evaluasi pembelajaran yang bias gender menjadi lebih responsif gender, sehingga siswa dapat memahami makna gender yang sebenarnya.

\section{B. Studi Literatur}

\section{Evaluasi Pembelajaran}

Sistem Pendidikan Nasional tertulis dalam UU No. 20 Tahun 2003 pasal 39 ayat 2 menyatakan bahwa pendidik adalah tenaga profesional yang ditugaskan merencanakan dan melaksanakan proses pembelajaran, menilai hasil pembelajaran, melakukan bimbingan dan pelatihan, serta melakukan penelitian dan pengabdian kepada masyarakat. Salah satu kompetensi yang harus dimiliki seorang pendidik adalah kemampuan mengadakan evaluasi, baik dalam proses pembelajaran maupun penilaian hasil belajar. ${ }^{15}$ Dalam dunia pendidikan, evaluasi selalu digunakan sebagai bahan rujukan untuk mengetahui hasil dari sebuah kegiatan. Pada periode tertentu, semua lembaga pendidikan (formal - non formal) selalu menggunakan evaluasi untuk mengetahui prestasi yang telah dicapai oleh siswa maupun hasil kinerja guru.

Tujuan pengajaran, pelaksanaan pengajaran, dan penilaian hasil pengajaran merupakan tiga komponen pengajaran yang tidak dapat dipisahkan. Secara tidak langsung ketiga komponen ini saling berkaitan satu sama lain, baik berkaitan dengan sebab akibat maupun dalam bentuk umpan balik. ${ }^{16}$ Tujuan pembelajaran yang sudah dirancang dijadikan sebagai

\footnotetext{
${ }^{14}$ Khusen, "Bias Gender Dalam Buku Pelajaran Bahasa Arab untuk Tingkat Madrasah Tsanawiyah Karya Darsono dan T. Ibrahim."

${ }^{15}$ Asrul Asrul, Rusydi Ananda, dan Rosnita Rosnita, Evaluasi Pembelajaran (Bandung: Citapustaka Media, 2015), 1.

${ }^{16}$ M. Sunardi Djiwandono, Tes Bahasa dalam Pengajaran (Bandung: Penerbit ITB Bandung, 1996), 3-6.
} 
rujukan dalam proses menyampaikan materi pembelajaran, dan menentukan metode yang akan digunakan. Begitu juga dengan bentuk tes dan alat evaluasi yang akan dipakai juga harus bersinggungan dengan materi yang telah disampaikan dan tujuan pembelajaran yang telah ditetapkan. ${ }^{17}$

Dalam kamus bahasa Inggris-Indonesia, kata "evaluasi" diadopsi dari kata "evaluation" (bahasa Inggris) yang berarti penilaian atau penaksiran. ${ }^{18}$ Dalam Kamus Besar Bahasa Indonesia (KBBI) evaluasi juga mempunyai arti penilaian. ${ }^{19}$ Sedangkan Sudjana mengartikan "penilaian" sebagai teknik untuk menentukan nilai suatu objek. ${ }^{20}$ Adapun pengertian evaluasi secara terminologi menurut pendapat William A. Mohrens dalam Asrul, dkk. adalah proses menggambarkan dan menyempurnakan informasi yang bermanfaat guna untuk menetapkan langkah. Seseorang dapat melakukan evaluasi baik dengan data kualitatif maupun kuantitatif, yang mana hasil evaluasi tersebut dapat dijadikan pedoman untuk memberi keputusan yang profesional. ${ }^{21}$ Dengan evaluasi guru dapat mengetahui keefektifan pembelajaran, baik dari segi materi yang disampaikan, metode, maupun media yang digunakan, dan hasil yang diperoleh bisa menjadi patokan guru untuk memperbaiki program pembelajaran pada pertemuan berikutnya. Sehingga evaluasi pembelajaran memiliki peran penting dalam program pembelajaran.

Secara umum, tujuan evaluasi pembelajaran adalah untuk memahami sejauh mana keberhasilan dan ketepatan sistem pembelajaran yang telah dirancang. Adapun tujuan penilaian hasil belajar antara lain: (1) untuk menemukan tingkat kemajuan, kompetensi, keterampilan, motivasi, minat bakat, dan relevansi hasil belajar siswa dalam program pembelajaran yang memenuhi standar kompetensi dan kompetensi dasar; (2) untuk menemukan keunggulan dan kelemahan siswa yang berpartisipasi dalam kegiatan pembelajaran. Keunggulan dan kelemahan tersebut dapat menjadi acuan bagi guru untuk memberikan bimbingan yang lebih lanjut kepada siswa; (3) digunakan untuk menyeleksi siswa sesuai dengan bidang yang diinginkan; (4) untuk kenaikan kelas; dan (5) untuk menempatkan siswa sesuai dengan kemampuannya. ${ }^{22}$

Fungsi evaluasi pembelajaran meliputi: (1) untuk memperbaiki dan mengembangkan sistem pembelajaran. Perbaikan dan pengembangan sistem

\footnotetext{
${ }^{17}$ Ridho, "Evaluasi Dalam Pembelajaran Bahasa Arab."

18 John M. Echols dan Hassan Shadily, English-Indonesia Dictionary (Jakarta: PT Gramedia Pustaka Utama, 2014), 220.

19 “KBBI (Kamus Besar Bahasa Indonesia) Daring,” diakses 15 April 2020, https://kbbi.kemdikbud.go.id/entri/evaluasi.

${ }^{20}$ Nana Sudjana, Penilaian Hasil Proses Belajar Mengajar (Bandung: Remaja Rosdakarya, 2017), 3.

${ }^{21}$ Asrul, Ananda, dan Rosnita, Evaluasi Pembelajaran, 2015, 3.

${ }^{22}$ Zainal Arifin, Evaluasi Pembelajaran (Bandung: Remaja Rosdakarya, 2009), 23.
} 
pembelajaran harus mengarah pada komponen pembelajaran, seperti tujuan pembelajaran, bahan ajar, metode pembelajaran, media pembelajaran, sumber belajar, guru dan siswa; (2) untuk akreditasi lembaga. Pembelajaran merupakan salah satu komponen utama dalam kegiatan akreditasi. Sehingga, hasil evaluasi pembelajaran juga menjadi salah satu berkas yang harus dilengkapi dalam persyaratan akreditasi sebuah lembaga pendidikan. Sedangkan penilaian hasil pembelajaran memiliki empat fungsi: (1) fungsi formatif, adalah memberikan umpan balik kepada guru sebagai dasar untuk meningkatkan program pembelajaran dan melakukan remedial kepada siswa; (2) fungsi sumatif, adalah untuk menentukan nilai hasil belajar siswa dalam mata pelajaran tertentu, sebagai data untuk dilaporkan ke berbagai pihak, dan sebagai sarana untuk menentukan kenaikan kelas dan kelulusan; (3) fungsi diagnosis, adalah untuk memecahkan masalah siswa dalam kesulitan belajar; (4) sebagai fungsi penempatan, adalah untuk menempatkan siswa dalam posisi pembelajaran yang sesuai (misalnya untuk menentukan program penjurusan) berdasarkan keahlian mereka. ${ }^{23}$

Evaluasi tes dan non-tes dapat digunakan dalam pembelajaran bahasa Arab. Adapun tes yang digunakan yaitu tes lisan dan tes tulis. Tes tulis digunakan untuk mengevaluasi keterampilan mendengarkan (maharah istima'), keterampilan membaca (maharah qira'ah) dari segi memahami bacaan, keterampilan menulis (maharah kitabah), dan tes lisan digunakan untuk mengevaluasi keterampilan berbicara (maharah kalam), dan keterampilan membaca (maharah qira'ah) dari segi membaca teks dengan baik dan benar. Tes tulis digunakan untuk mengukur tingkat kemahiran siswa dalam memahami materi bahasa arab yang telah disampaikan oleh guru. Sedangkan tes lisan digunakan untuk mengukur kemampuan siswa dalam berbicara menggunakan bahasa Arab. ${ }^{24}$

\section{Gender Dan Jenis Kelamin}

Kadarusman menjelaskan, kata gender (dibaca jender) diadopsi dari kata "gender" berasal dari bahasa Inggris yang berarti jenis kelamin. ${ }^{25}$ Moffatt dkk. mendefinisikan jenis kelamin adalah perbedaan biologis dan kodrati antara laki-laki dan perempuan baik dari ciri fisik primer dari organ dan fungsi reproduksinya maupun ciri-ciri sekunder. Sedangkan gender didefinisikan sebagai perbedaan sifat, peran, dan kedudukan sosial antara laki-laki dan perempuan sebagai hasil interpretasi budaya dalam kehidupan keluarga dan masyarakat. ${ }^{26}$ Sedangkan Fakih memaknai gender sebagai

\footnotetext{
${ }^{23}$ Arifin, 28.

${ }^{24}$ Miladya, "Evaluasi Dalam Pembelajaran Bahasa Arab."

${ }^{25}$ Kadarusman Kadarusman, Agama, Relasi Gender dan Feminisme (Yogyakarta: Kreasi Wacana, 2005), 19.

${ }^{26}$ Michelle Moffatt dkk., Gender \& Pendidikan (IAPBE, 2007), 7.
} 
karakter yang sudah ada pada diri laki-laki dan perempuan sebagai hasil konstruksi sosial dan budaya. ${ }^{27}$ Seperti menganggap sifat rasional, kuat, jantan, superior dan maskulin merupakan sifat yang dekat pada diri laki-laki, sedangkan sifat keibuan, lemah lembut, penakut, emosional, feminin, dan inferior merupakan sifat yang dekat pada diri perempuan. Sifat-sifat ini tidak selamanya melekat pada kedua jenis kelamin tersebut. Ada kalanya sifat-sifat yang terdapat di diri laki-laki bertukar dengan perempuan, begitu juga sebaliknya. Bahkan Nasaruddin Umar dalam Fatchurrozaq mempunyai pandangan bahwa, gender adalah konsep budaya yang digunakan untuk memberikan justifikasi perbedaan perilaku, peran dan yang lainnya antara laki-laki dan perempuan yang direkayasa oleh sosial, sehingga menjadi berkembang di masyarakat luas. ${ }^{28}$ Merujuk dari beberapa pengertian tersebut diketahui bahwa jenis kelamin dan gender memiliki perbedaan yang jauh. Jenis kelamin lebih pada bentuk perbedaan biologis yang bersifat permanen, sedangkan gender, pemetaan peranan dan hubungan seseorang sewaktuwaktu dapat berubah, dan sifatnya dibentuk oleh sosial dan budaya setempat. Berikut tabel perbedaan antara jenis kelamin dan gender:

Tabel 1: Perbedaan Laki-Laki dan Perempuan Berdasarkan Jenis Kelamin ${ }^{29}$

\begin{tabular}{ccc}
\hline Kategori & Laki-Laki & Perempuan \\
\hline Identitas Jenis & Penis, Sperma, & Vagina, Rahim, \\
Kelamin & Testis, Jakun & Ovum, ASI \\
Peran Biologis & Membuahi & Menstruasi, Hamil, \\
& (Spermatozoa) & Melahirkan, Menyusui \\
\hline
\end{tabular}

Tabel 2: Perbedaan Laki-Laki dan Perempuan dalam Gender ${ }^{30}$

\begin{tabular}{ccc}
\hline Gender & Laki-laki & Perempuan \\
\hline Sifat & Maskulin & Feminim \\
Peran dan Fungsi & Produksi & Reproduksi \\
Ruang Lingkup & Publik & Domestik \\
Tanggung jawab & Nafkah Utama & Nafkah Tambahan \\
\hline
\end{tabular}

${ }^{27}$ Mansour Fakih, Analisis Gender dan Transformasi Sosial (Yogyakarta: Insist Press, 2008), 8.

${ }^{28}$ Fatchurrozaq, "Pengembangan Bahan Ajar Modul Bahasa Arab Berperspektif Gender Bagi Siswa Kelas VII Madrasah Tsanawiyah," 2018.

${ }^{29}$ Agung Setiyawan, "Mudzakkar Dan Muannats: Sumber Pendidikan Islam Bias Gender," Jurnal Pendidikan Islam 3, no. 2 (2014): 245, https://doi.org/10.14421/jpi.2014.32.245-266.

${ }^{30}$ Moffatt dkk., Kebijakan dan Anggaran Pendidikan Dasar Responsif Gender 2, 9. 
Tabel 3: Perbedaan Jenis Kelamin dan Gender ${ }^{31}$

\begin{tabular}{cc}
\hline Identitas Jenis Kelamin & Identitas Gender \\
\hline Menyangkut ciri & Menyangkut ciri, peran \\
dan fungsi biologis & dan posisi sosial \\
Khas bagi laki-laki & Dapat ditemukan \\
dan perempuan & dan dilakukan oleh laki-laki \\
Universal dan & Relatif, kontekstual, \\
berlaku secara umum & dan kondisional \\
Tidak dapat berubah & Sesuai kebutuhan \\
\hline
\end{tabular}

\section{Kesetaraan Gender, Keadilan Gender, dan Bias Gender}

Perbedaan jenis kelamin yang telah ditetapkan oleh Allah bersifat kodrati. Yang mana perbedaan ini tidak dapat dipertukarkan dan berlaku sepanjang zaman. Namun laki-laki dan perempuan memiliki kesetaraan gender dalam mengemban amanah Allah di muka bumi. Kesetaraan gender merupakan kesamaan hak-hak dasarnya di hadapan Allah dan sesama manusia agar setiap manusia menghormati saudaranya sesama manusia apakah dia laki-laki atau perempuan. Proses untuk menuju kesetaraan gender perlu adanya keadilan gender. Dimana laki-laki dan perempuan yang telah diberi hak-hak dasarnya, potensi diri, dan alam seisinya oleh Allah dapat digunakan sebagai modal untuk beramal saleh, berprestasi, dan beraktualisasi diri agar setiap manusia laki-laki maupun perempuan mendapatkan hakhaknya secara adil. ${ }^{32}$

Selanjutnya, yang dimaksud dengan bias gender adalah pandangan dan sikap yang lebih mengutamakan salah satu jenis kelamin tertentu daripada jenis kelamin lainnya sebagai akibat pengaturan dan kepercayaan budaya. ${ }^{33}$ Adapun bentuk manifestasi dari bias gender meliputi:

1) Stereotype adalah pelabelan dengan konotasi negatif terhadap jenis kelamin laki-laki atau perempuan sehingga sering menimbulkan konflik. Secara umum pelabelan negatif selalu melahirkan ketidakadilan. Misalnya pandangan masyarakat terhadap laki-laki selalu dianggap kasar, kuat, berpikir rasional, sedangkan perempuan selalu dianggap lemah, cerewet, suka bawa perasaan. Hal ini menimbulkan kesan negatif;

2) Subordinasi merupakan suatu anggapan atau penilaian tidak adil terhadap salah satu jenis kelamin yang menyebabkan penempatan status, peran, dan relasi salah satu jenis kelamin tidak setara dan adil. Nilai-nilai yang

\footnotetext{
${ }^{31}$ Moffatt dkk., Gender \& Pendidikan, 2007, 8.

${ }^{32}$ Mufidah Cholil, "Suplemen Modul Gender dan Agama," tidak dipublikasikan.

${ }^{33}$ Michelle Moffatt dkk., Panduan Penggunaan Gender KIT untuk Program Pendidikan Dasar (IAPBE, 2007), 7.
} 
berjalan di masyarakat ini telah memisah-misahkan dan membedabedakan peran laki-laki dan perempuan. Perempuan dianggap bertanggung jawab dalam urusan domestik, sedangkan laki-laki bertanggung jawab dalam urusan publik;

3) Marginalisasi adalah proses menyingkirkan salah satu jenis kelamin yang disebabkan oleh perbedaan jenis kelamin baik sengaja maupun tidak sengaja yang menimbulkan kemiskinan. Salah satu cara efektif untuk menyingkirkan individu atau kelompok adalah menggunakan asumsi gender. Perempuan merupakan korban dalam marginalisasi. Penyingkiran terhadap perempuan tidak hanya terjadi di dunia kerja, namun juga ada di kehidupan rumah tangga, masyarakat, budaya, maupun negara;

4) Violence (kekerasan) yang berarti salah satu jenis kelamin mendapatkan tindak kekerasan baik fisik maupun non fisik dari jenis kelamin lainnya dalam kehidupan keluarga, masyarakat, atau negara. Perbedaan gender sering menjadi masalah karena timbul ketidakadilan dari salah satu jenis kelamin. Disini kaum perempuan sering kali tidak diposisikan setara dengan laki-laki sehingga mereka sering menjadi target tindak kekerasan (violence) oleh kaum laki-laki. Kekerasan tidak hanya menyangkut serangan fisik saja tetapi juga dalam bentuk non fisik, seperti bahasa dan ungkapan yang digunakan berbentuk pelecehan dan diskriminasi sehingga dapat mengganggu psikis seseorang;

5) Beban ganda yaitu salah satu jenis kelamin mendapatkan tanggung jawab pekerjaan yang lebih banyak dibandingkan jenis kelamin lainnya. Perempuan yang identik sebagai konco wingking sering kali dianggap bahwa pekerjaan rumah tangga adalah tugas pokok perempuan. Walaupun sekarang ini jumlah perempuan yang bekerja di wilayah publik sudah mengalami peningkatan, namun mereka masih tetap memiliki tanggung jawab di wilayah domestik. ${ }^{34}$

Perbedaan gender tidak masalah jika tidak ada ketidaksetaraan gender. Namun faktanya, perbedaan gender telah melahirkan ketidakadilan terhadap salah satu jenis kelamin. Bentuk ketidaksetaraan gender ini saling tumpang tindih dan memiliki dampak satu sama lain, dimana laki-laki dan perempuan menjadi korban sistem gender. Sebagai contoh, marginalisasi perempuan dikaitkan dengan stereotip dari beberapa perempuan, dan pada akhirnya masyarakat mempercayainya. Karena itu, tidak mungkin untuk menentukan apakah keadilan yang dominan disebabkan oleh faktor-faktor tertentu seperti marginalisasi atau kekerasan saja. Sehingga bias gender ada karena adanya ketidaksetaraan dan ketidakadilan gender.

${ }^{34}$ Fatchurrozaq, "Pengembangan Bahan Ajar Modul Bahasa Arab Berperspektif Gender Bagi Siswa Kelas VII Madrasah Tsanawiyah," 2018. 


\section{Metode Penelitian}

Penelitian ini menggunakan pendekatan kualitatif yang bertujuan untuk mendeskripsikan ragam gender yang termuat dalam soal ujian madrasah. ${ }^{35}$ Adapun jenis penelitian yang digunakan adalah library research (studi pustaka) yaitu, jenis penelitian yang dilakukan dengan cara mengumpulkan data-data yang bersumber dari buku, jurnal, artikel, dan tulisan-tulisan tertentu. ${ }^{36}$ Sumber data primer berasal dari jurnal-jurnal ilmiah yang berkaitan gender, dan lembar soal ujian madrasah. Sedangkan sumber data sekunder diperoleh dari wawancara, buku, dan rujukan lain yang berkaitan dengan pembahasan ini. ${ }^{37}$

Teknik yang digunakan dalam pengumpulan data berupa wawancara, angket dan dokumentasi. Wawancara dilakukan kepada guru mata pelajaran bahasa Arab kelas IX untuk mengetahui seputar proses pembuatan soal ujian madrasah. Teknik angket digunakan untuk penilaian ragam gender yang termuat dalam soal ujian madrasah, sedangkan teknik dokumentasi digunakan untuk mengulas lebih dalam soal ujian madrasah yang berorientasi pada bias gender.

Analisis data dilakukan dengan tiga tahapan yaitu pengumpulan data, penyajian data dan penarikan kesimpulan. ${ }^{38}$ Langkah pertama, pengumpulan data diperoleh melalui wawancara, angket dan dokumentasi. Langkah kedua, data disajikan dalam bentuk tabel untuk diidentifikasi jumlah soal yang bermuatan ragam gender. Selanjutnya, penilaian soal ujian yang berorientasi pada bias gender dilakukan dalam bentuk grafik agar mudah dipahami. Langkah ketiga memberikan kesimpulan dari hasil penyajian data.

Data yang dikumpulkan melalui instrumen angket dianalisis menggunakan skala Guttman. ${ }^{39}$ Adapun skoring perhitungan dalam skala Guttman sebagai berikut:

Tabel 4: Skoring Skala Guttman

\begin{tabular}{cc}
\hline Alternatif Jawaban & Skor Alternatif Jawaban \\
\hline Ya & 1 \\
Tidak & 0 \\
\hline
\end{tabular}

${ }^{35}$ Mukhtar, Metode Praktis Penelitian Deskriptif Kualitatif (Jakarta: GP Press Group, 2013), 28.

${ }^{36}$ Moh. Nazir, Metode Penelitian (Bogor: Ghalia Indonesia, 2013), 93.

${ }^{37}$ Suharsimi Arikunto, Prosedur Penelitian Suatu Pendekatan Praktik (Jakarta: Rineka Cipta, 2010), 161.

${ }^{38}$ Arif Widodo dkk., "Analisis Konten HOTS dalam Buku Siswa Kelas V Tema 6 'Panas dan Perpindahannya' Kurikulum 2013," Madrasah: Jurnal Pendidikan dan Pembelajaran Dasar 12, no. 1 (2019): 1-13, https://doi.org/10.18860/mad.v12i1.7744.

${ }^{39}$ Usman Rianse dan Abdi Abdi, Metodologi Penelitian Sosial dan Ekonomi: Teori dan Aplikasi (Bandung: Alfabeta, 2011), 155. 
Keterangan:

Jawaban dibuat dengan skor tertinggi "satu" dan skor terendah "nol. Untuk alternatif jawaban dalam angket, penulis menetapkan kategori "Ya $=1$ " dan kategori "Tidak $=0$ ". Dalam penelitian ini penulis menggunakan skala Guttman dalam bentuk checklist, dengan harapan akan didapatkan jawaban yang tegas mengenai data yang diperoleh.

Data yang diperoleh secara kuantitatif perlu diolah untuk proses penarikan kesimpulan. Teknik statistik yang digunakan dalam penelitian ini adalah persentase..$^{40}$ Adapun rumusnya sebagai berikut:

$P=\frac{f}{N} \times 100 \%$

Keterangan:

P : Persentase

f : frekuensi dari setiap jawaban yang dipilih

$\mathrm{N}$ : Jumlah soal

$100 \%$ : Konstanta

Selanjutnya persentase yang diperoleh diterjemahkan ke dalam kategori berikut:

Tabel 5: Kategori Persentase

\begin{tabular}{cc}
\hline Persentase & Kategori \\
\hline $0-1 \%$ & Tidak ada \\
$2-25 \%$ & Sebagian kecil \\
$25-49 \%$ & Kurang dari setengahnya \\
$50 \%$ & Setengahnya \\
$51 \%-75 \%$ & Lebih dari setengahnya \\
$76 \%-99 \%$ & Sebagian besar \\
$100 \%$ & Seluruhnya \\
\hline
\end{tabular}

\section{Hasil dan Pembahasan}

Penulis melakukan pengumpulan data soal ujian madrasah. Instrumen yang digunakan untuk mengetahui jumlah soal termuat dalam ragam gender pada soal ujian madrasah adalah angket. Ragam gender dibatasi dengan tiga aspek, yaitu kesetaraan gender, netral gender, dan bias gender dengan hasil sebagai berikut:

${ }^{40}$ Mutia Risma, Rahmayani Rahmayani, dan Fitria Handayani, “Analisis Konten Buku Teks IPA Terpadu Kelas VIII Semester 1 Ditinjau Dari Aspek Literasi Saintifik," JURNAL EKSAKTA PENDIDIKAN (JEP) 3, no. 2 (2019): 200-208, https://doi.org/10.24036/jep/vol3iss $2 / 396$. 
Tabel 6: Hasil Angket

\begin{tabular}{ccc}
\hline Ragam Gender & Nomor Soal & Jumlah Soal \\
\hline Kesetaraan Gender & $3,4,22,23$ & 4 \\
& $5,6,8,11,12,13,14,15,16,17,18$, & \\
Netral Gender & $\begin{array}{c}19,20,26,29,30,31,32,35,38,39, \\
\text { 40, 41, 42, 43, 44, 46, 47, 49,50 }\end{array}$ \\
Bias Gender & $\begin{array}{c}1,2,7,9,10,21,24,25,27, \\
28,33,34,36,37,45,48\end{array}$ & 16 \\
& Total & $\mathbf{5 0}$ \\
\hline
\end{tabular}

Dari tabel 6 di atas dapat diketahui bahwa soal yang bermuatan kesetaraan gender terdiri dari 4 soal, netral gender terdiri dari 30 soal, dan bias gender terdiri dari 16 soal. Selanjutnya, setiap ragam gender dibandingkan dalam bentuk persentase. Hasil analisis disajikan dalam bentuk grafik berikut:

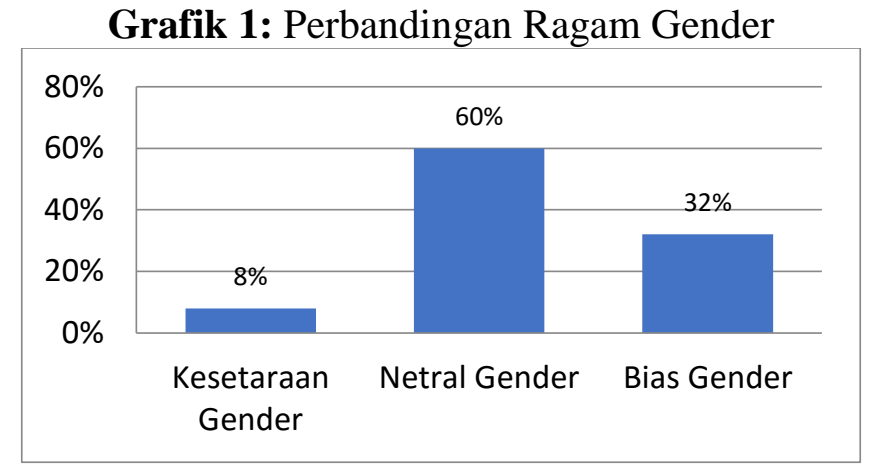

Grafik 1 di atas menunjukkan bahwa hasil dari kesetaraan gender, netral gender, dan bias gender yaitu $8 \%, 60 \%$, dan 32\%. Hal ini menunjukkan bahwa soal yang bermuatan netral gender memperoleh hasil paling tinggi yaitu $60 \%$, dan soal yang bermuatan kesetaraan gender memperoleh hasil paling rendah yaitu 8\%. Merujuk pada analisis Guttman, jumlah soal yang bermuatan bias gender sebanyak 16 soal, dengan persentase sebesar $32 \%$. Sehingga dapat disimpulkan bahwa soal ujian madrasah kurang dari setengahnya berorientasi pada bias gender.

Evaluasi pembelajaran merupakan bahan tolok ukur penentuan nilai siswa, sehingga dapat diketahui hasil dan kualitasnya. ${ }^{41}$ Selain pendidik dan pemerintah, evaluasi juga dilaksanakan oleh satuan pendidikan. Satuan pendidikan melakukan evaluasi pada akhir jenjang pendidikan bertujuan untuk penentuan kelulusan. Sejalan dengan Keputusan Menteri Agama (KMA) No. 165 tahun 2014 tentang Kurikulum 2013 mata pelajaran 2011), 4.

\footnotetext{
${ }^{41}$ Gito Supriyadi, Pengantar Teknik Evaluasi Pembelajaran (Malang: Intimedia,
} 
Pendidikan Agama Islam dan bahasa Arab pada Madrasah tentang standar penilaian. Di sana dijelaskan bahwa ujian madrasah yang dilakukan oleh satuan pendidikan adalah untuk mengukur pencapaian kompetensi kelulusan siswa di luar kompetensi yang diujikan pada Ujian Nasional (UN). Oleh karena itu, soal yang diujikan harus sesuai dengan prinsip penilaian yang sudah diatur dalam undang-undang.

Analisis gender di sini adalah analisis terhadap kesetaraan peran publik antara laki-laki dan perempuan yang tercantum dalam soal ujian madrasah baik dari segi teks maupun gambar. Sesuai dengan pengertian gender yaitu sebuah konsep yang dijadikan sebagai tolok ukur dalam pengidentifikasian peran laki-laki dan perempuan yang didasarkan pada pengaruh sosial budaya masyarakat. ${ }^{42}$ Adapun analisis terhadap ragam gender dibatasi menjadi tiga, yaitu kesetaraan gender, netral gender, dan bias gender.

Kesetaraan gender merupakan perilaku kesamaan kondisi bagi laki-laki dan perempuan untuk memperoleh kesempatan serta hak-haknya sebagai manusia agar mampu berpartisipasi dalam kegiatan politik, ekonomi, sosial, budaya, pendidikan, pertahanan dan keamanan nasional, serta mendapatkan kesamaan dalam menikmati hasil pembangunan. ${ }^{43}$ Kesetaraan gender dalam konteks evaluasi yaitu soal yang dirancang dengan memberikan kesamaan kondisi serta hak untuk kaum laki-laki dan perempuan. Soal ujian madrasah yang mengandung kesetaraan gender sebanyak 4 soal dengan persentase $8 \%$. Adapun contoh soal yang mengandung kesetaraan gender sebagai berikut:

\begin{tabular}{|c|c|}
\hline 1 & 2 \\
\hline 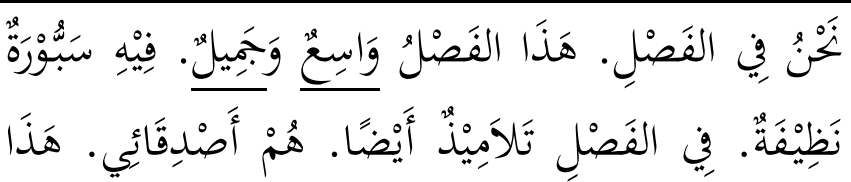 & 4 \\
\hline 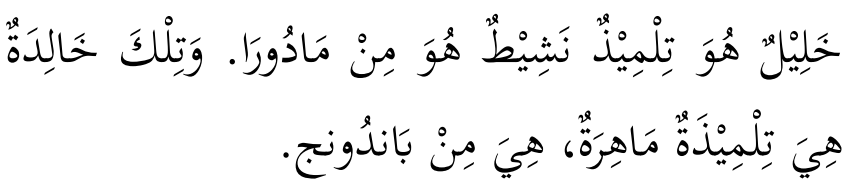 & \\
\hline 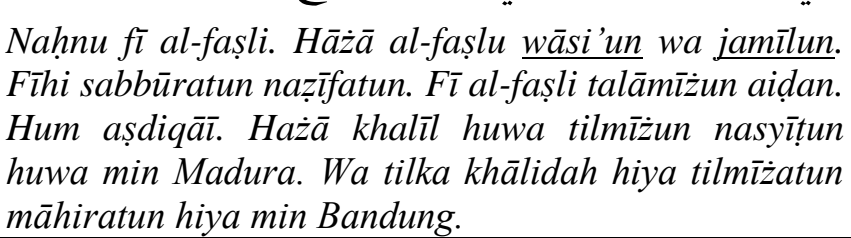 & 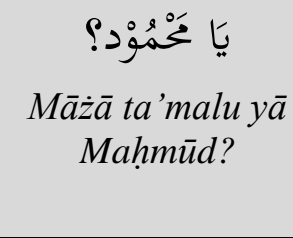 \\
\hline
\end{tabular}

\footnotetext{
42 Hasnah, "Bias Gender Dalam Buku Ajar Al-Arabiyah Linnaasyiin."

${ }^{43}$ Favian Rizky Taufik, "Analisis Gender Terhadap Ilustrasi Teks Dan Ilustrasi Gambar Dalam Buku Pelajaran Bidang Studi Akidah Akhlak MTS Kelas IX Penerbit Kementerian Agama Tahun 2016" (Skripsi, Universitas Islam Negeri Sunan Ampel Surabaya, 2020), http://digilib.uinsby.ac.id/44576/.
} 
Dari hasil analisis data diketahui bahwa soal-soal yang mengandung kesetaraan gender adalah teks yang disajikan dengan melibatkan dua jenis kelamin sekaligus. Sedangkan gambar yang disajikan menunjukkan kesetaraan peran dan hak antara dua jenis kelamin dalam suatu aktivitas.

Netral gender adalah suatu norma menghindari pembedaan peran jenis kelamin. Menghindari diskriminasi yang timbul agar tidak ada kesan mengunggulkan salah satu jenis kelamin saja. ${ }^{44}$ Dalam konteks evaluasi, soal netral gender mencakup soal yang dirancang dengan tidak memihak pada salah satu jenis kelamin. Soal ujian madrasah yang mengandung netral gender sebanyak 30 soal dengan persentase $60 \%$. Berikut contoh soal netral gender:

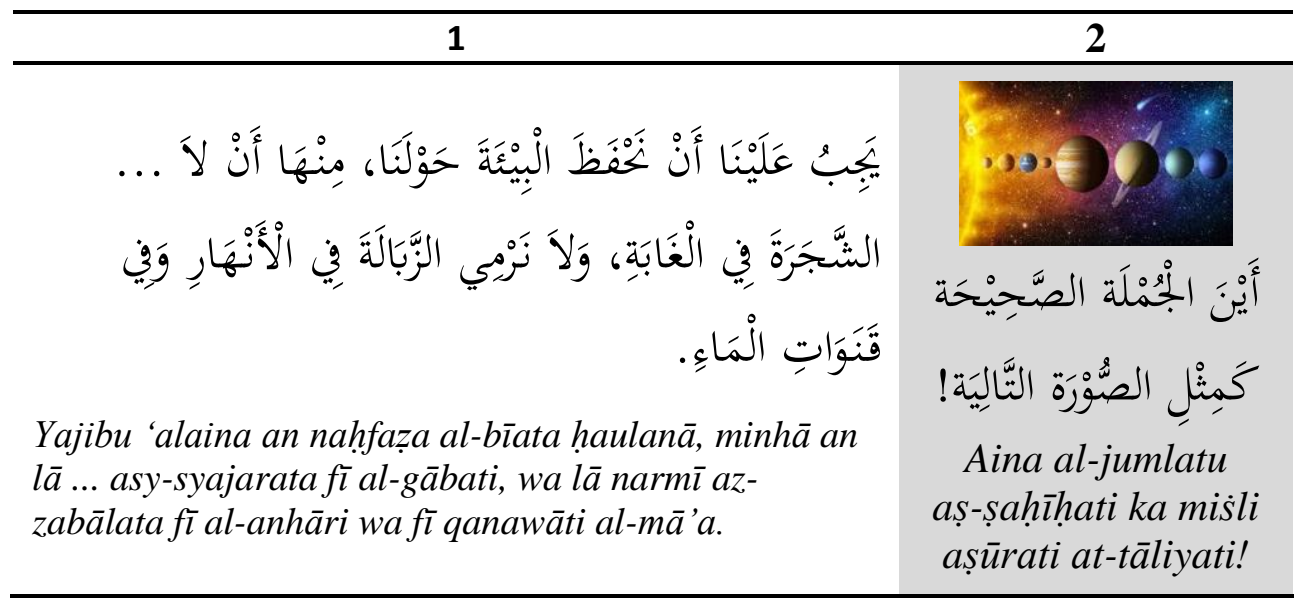

Dari hasil analisis data, soal-soal yang mengandung netral gender menggunakan teks yang umum berdasarkan konteksnya sehingga tidak mengarah pada kesetaraan maupun bias gender. Sementara dari segi gambar disajikan sesuai pada konteksnya dalam bentuk abstrak sehingga tidak berpihak pada salah satu jenis kelamin.

Bias gender merupakan kondisi dimana terjadi kesenjangan saat salah satu jenis kelamin digambarkan tidak setara. Penggambaran ketidaksetaraan ini mengarah pada munculnya keunggulan pada salah satu jenis kelamin. ${ }^{45}$ Dalam konteks evaluasi, soal bias gender mencakup soal-soal yang dirancang dengan menunjukkan ketimpangan gender. Soal ujian madrasah

44 Taufik.

45 Billah Nurlaili Zulmi, "Bias Gender dalam Buku Tematik Siswa Kurikulum 2013 (Studi Semiotika Ketidaksetaraan Gender dalam Pendidikan)," Paradigma: Jurnal Online Mahasiswa S1 Sosiologi UNESA 5, no. 3 (2017): 253229, https://www.neliti.com/id/publications/253229/. 
yang mengandung bias gender sebanyak 16 soal dengan persentase $32 \%$. Di bawah ini contoh soal yang mengandung bias gender:

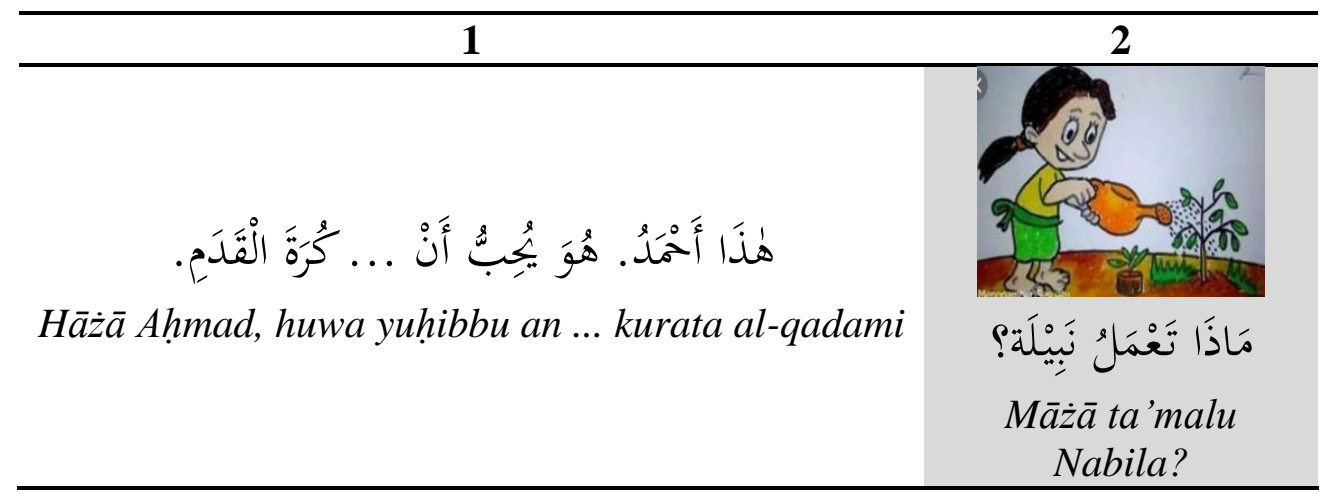

Dari hasil analisis data, soal-soal yang mengandung bias gender menggunakan kalimat atau gambar disajikan dengan memihak kepada salah satu jenis kelamin dengan hanya memunculkan satu jenis kelamin saja berdasarkan stereotype dan subordinasi.

Berdasarkan hasil wawancara kepada salah satu guru bahasa Arab yang ikut andil dalam pembuatan soal ujian madrasah diketahui bahwa soal ujian madrasah untuk mata pelajaran bahasa Arab disusun oleh para guru Madrasah Tsanawiyah yang tergabung dalam forum MGMP (Musyawarah Guru Mata Pelajaran) bahasa Arab se-kota Malang. Dalam proses penyusunan dan analisis butir soal tidak ditemukan adanya ketentuan terhadap responsif gender pada butir soal. Ketentuan dalam penyusunan butir soal sesuai dengan materi yang terdapat di kelas VII sampai kelas IX. Adapun analisis butir soal ditinjau dari aspek materi, konstruksi, dan bahasa. Sehingga guru mengabaikan aspek gender dalam menyusun dan menganalisis butir soal. Hal ini dibuktikan dengan kurang dari setengah soal ujian madrasah berorientasi pada bias gender dengan persentase sebesar 32\% atau sebanyak 16 soal. Meskipun kurang dari 50\% berorientasi bias gender, jika tidak segera ditindaklanjuti maka akan berdampak buruk pada pola pikir siswa tentang apa yang layak dan tidak layak dilakukan oleh laki-laki dan perempuan melalui teks yang dibaca, dan gambar yang dilihat. ${ }^{46}$ Guru yang sadar gender dengan kreatif akan mengubah tokoh dalam teks atau gambar yang berwawasan kesetaraan gender. ${ }^{47}$ Penanaman nilai-nilai berperspektif kesetaraan gender penting untuk dilakukan agar tercipta siswa yang

${ }^{46}$ Zubaidah Amir Mz, "Perspektif Gender Dalam Pembelajaran Matematika,"

Marwah: Jurnal Perempuan, Agama Dan Jender 12, no. 1 (2013): 15-31, https://doi.org/10.24014/marwah.v12i1.511.

${ }^{47}$ Hasnah, "Bias Gender Dalam Buku Ajar Al-Arabiyah Linnaasyiin." 
berkeadilan gender, saling menghormati dan menghargai antar sesama serta merasakan kesetaraan tanpa membeda-bedakan. ${ }^{48}$

Adapun kiat dalam menyusun soal ujian berbasis responsif gender di antaranya: 1) Peran gender yang seimbang. Peran yang selama ini disandang laki-laki dapat pula disandang oleh perempuan, demikian juga sebaliknya; 2) Jenis kelamin disajikan dengan adil (melibatkan dua jenis kelamin sekaligus); 3) Bersifat kepentingan manusia yang relevan dengan kehidupan nyata; dan 4) Menggunakan bahasa komunikatif agar mudah dipahami. ${ }^{49}$

\section{E. Kesimpulan}

Berdasarkan pada analisis soal ujian madrasah bahasa Arab kelas IX, dapat penulis tarik kesimpulan sebagai berikut: pertama, Soal yang bermuatan kesetaraan gender terdiri dari 4 soal atau $8 \%$, netral gender terdiri dari 30 soal atau $60 \%$, dan bias gender terdiri dari 16 soal atau $32 \%$. Sehingga soal yang bermuatan netral gender memperoleh hasil paling tinggi, sedangkan soal yang bermuatan kesetaraan gender memperoleh hasil paling rendah. Kedua, diketahui bersama bahwa kurang dari setengah soal ujian madrasah berorientasi pada bias gender dengan persentase sebesar 32\% atau 16 soal. Meskipun di bawah dari 50\%, hal ini dapat berdampak buruk pada pola pikir siswa tentang apa yang layak dan tidak layak dilakukan oleh lakilaki atau perempuan. Saran peneliti kepada para guru bahasa Arab untuk membiasakan diri dengan memperhatikan nilai responsif gender dalam membuat soal evaluasi pembelajaran. Minimal dimulai dari membuat soal harian. Ketika sudah terbiasa nantinya akan ditingkatkan ke penilaian tengah semester dan penilaian akhir semester. Selain itu, diharapkan kepada penulis selanjutnya untuk melakukan penelitian yang lebih mendalam, sehingga dapat melengkapi kekurangan dari artikel ini.

\footnotetext{
${ }^{48}$ Fatchurrozaq, "Pengembangan Bahan Ajar Modul Bahasa Arab Berperspektif Gender Bagi Siswa Kelas VII Madrasah Tsanawiyah," 2018.

${ }^{49}$ Wagiran, “Kasus Bias Gender dalam Pembelajaran” (Universitas Negeri Yogyakarta), diakses 30 Desember 2020, http://staffnew.uny.ac.id/upload/132297916/lainlain/Kiat+Menulis+Bahan+Ajar+Berwawa san+Gender.pdf.
} 


\section{Daftar Pustaka}

Arifin, Zainal. Evaluasi Pembelajaran. Bandung: Remaja Rosdakarya, 2009.

Arikunto, Suharsimi. Prosedur Penelitian Suatu Pendekatan Praktik. Jakarta:

Rineka Cipta, 2010.

Arikunto, Suharsimi, Abdul Jabar, dan Cepi Safruddin. Evaluasi Program

Pendidikan: Pedoman Teoritis Praktis Bagi Praktisi Pendidikan.

Jakarta: Bumi Aksara, 2007.

Asrul, Asrul, Rusydi Ananda, dan Rosnita Rosnita. Evaluasi Pembelajaran.

Bandung: Citapustaka Media, 2015.

Cholil, Mufidah. "Suplemen Modul Gender dan Agama," tidak

dipublikasikan.

Djiwandono, M. Sunardi. Tes Bahasa dalam Pengajaran. Bandung: Penerbit ITB Bandung, 1996.

Echols, John M., dan Hassan Shadily. English-Indonesia Dictionary. Jakarta:

PT Gramedia Pustaka Utama, 2014.

Fakih, Mansour. Analisis Gender dan Transformasi Sosial. Yogyakarta: Insist Press, 2008.

Fatchurrozaq, Irsyad Kholis. "Pengembangan Bahan Ajar Modul Bahasa Arab Berperspektif Gender Bagi Siswa Kelas VII Madrasah Tsanawiyah."

El-Wasathiya: Jurnal Studi Agama 6, no. 2 (2018): 193-221.

http://ejournal.kopertais4.or.id/mataraman/index.php/washatiya/a rticle/view/3553.

Hasnah, Nur. "Bias Gender Dalam Buku Ajar Al-Arabiyah Linnaasyiin."

HUMANISMA : Journal of Gender Studies 1, no. 1 (2017): 61-74.

https://ejournal.iainbukittinggi.ac.id/index.php/psga/article/view/3

24.

Kadarusman, Kadarusman. Agama, Relasi Gender dan Feminisme.

Yogyakarta: Kreasi Wacana, 2005.

“KBBI (Kamus Besar Bahasa Indonesia) Daring.” Diakses 15 April 2020.

https://kbbi.kemdikbud.go.id/entri/evaluasi.

Khusen, Maulana. "Bias Gender Dalam Buku Pelajaran Bahasa Arab untuk

Tingkat Madrasah Tsanawiyah Karya Darsono dan T. Ibrahim." Jurnal

IImiah Mahasiswa Raushan Fikr 3, no. 2 (2014): 115.

https://doi.org/10.24090/jimrf.v3i2.1023.

Maslihah, Rizka Eliyana. "Nilai Responsif Gender Dalam Pembelajaran

Bahasa Arab." Al Mahāra: Jurnal Pendidikan Bahasa Arab 4, no. 2

(2018): 181. https://doi.org/10.14421/almahara.2018.042-02.

Miladya, Junda. "Evaluasi Dalam Pembelajaran Bahasa Arab." Prosiding

Konferensi Nasional Bahasa Arab 1, no. 1 (2015). 
http://prosiding.arab-

um.com/index.php/konasbara/article/view/21.

Moffatt, Michelle, Siti Ruhaini Dzuhayatin, Mufidah Cholil, dan Alfianda

Mariawati. Gender \& Pendidikan. IAPBE, 2007.

-- - Kebijakan dan Anggaran Pendidikan Dasar Responsif Gender 2. Indonesia Australia Partnership In Basic Education, 2007.

- - . Panduan Penggunaan Gender KIT untuk Program Pendidikan Dasar. IAPBE, 2007.

Moh. Nazir. Metode Penelitian. Bogor: Ghalia Indonesia, 2013.

Mukhtar. Metode Praktis Penelitian Deskriptif Kualitatif. Jakarta: GP Press Group, 2013.

Mulyadi, Achmad. "Relasi Laki-Laki Dan Perempuan (Menabrak Tafsir Teks, Menakar Realitas)." Al-Ihkam: Jurnal Hukum Dan Pranata Sosial 7, no. 2 (2014): 247-61.

http://ejournal.iainmadura.ac.id/index.php/alihkam/article/view/32 7.

Muttaqin, Zaenal, Momon Mujiburrohman, dan Faruq Baharudin. Buku Siswa Bahasa Arab Kelas VII. Jakarta: Kementerian Agama, 2014.

$\mathrm{Mz}$, Zubaidah Amir. "Perspektif Gender Dalam Pembelajaran Matematika."

Marwah: Jurnal Perempuan, Agama Dan Jender 12, no. 1 (2013):

15-31. https://doi.org/10.24014/marwah.v12i1.511.

Rianse, Usman, dan Abdi Abdi. Metodologi Penelitian Sosial dan Ekonomi:

Teori dan Aplikasi. Bandung: Alfabeta, 2011.

Ridho, Ubaid. "Evaluasi Dalam Pembelajaran Bahasa Arab." An Nabighoh:

Jurnal Pendidikan Dan Pembelajaran Bahasa Arab 20, no. 01 (2018):

19-26. https://doi.org/10.32332/an-nabighoh.v20i01.1124.

Risma, Mutia, Rahmayani Rahmayani, dan Fitria Handayani. "Analisis

Konten Buku Teks IPA Terpadu Kelas VIII Semester 1 Ditinjau Dari

Aspek Literasi Saintifik." JURNAL EKSAKTA PENDIDIKAN (JEP) 3, no. 2

(2019): 200-208. https://doi.org/10.24036/jep/vol3-iss2/396.

Setiyawan, Agung. "Mudzakkar Dan Muannats: Sumber Pendidikan Islam

Bias Gender." Jurnal Pendidikan Islam 3, no. 2 (2014): 245.

https://doi.org/10.14421/jpi.2014.32.245-266.

Shodiq, Muhammad Jafar. "Perspektif Kesetaraan Gender Dalam Buku

Bahasa Arab Siswa MTs Pendekatan Saintifik 2013." FENOMENA 8, no. 1 (2016): 01-18. https://doi.org/10.21093/fj.v8i1.302.

Sudjana, Nana. Penilaian Hasil Proses Belajar Mengajar. Bandung: Remaja

Rosdakarya, 2017. 
Supriyadi, Gito. Pengantar Teknik Evaluasi Pembelajaran. Malang: Intimedia, 2011.

Taufik, Favian Rizky. "Analisis Gender Terhadap Ilustrasi Teks Dan Ilustrasi Gambar Dalam Buku Pelajaran Bidang Studi Akidah Akhlak MTS Kelas IX Penerbit Kementerian Agama Tahun 2016." Skripsi, Universitas Islam Negeri Sunan Ampel Surabaya, 2020. http://digilib.uinsby.ac.id/44576/.

Wagiran. "Kasus Bias Gender dalam Pembelajaran." Universitas Negeri Yogyakarta. Diakses 30 Desember 2020.

http://staffnew.uny.ac.id/upload/132297916/lainlain/Kiat+Menulis+ Bahan+Ajar+Berwawasan+Gender.pdf.

Widodo, Arif, Dyah Indraswati, Radiusman Radiusman, Umar Umar, dan Nursaptini Nursaptini. "Analisis Konten HOTS dalam Buku Siswa Kelas V Tema 6 'Panas dan Perpindahannya' Kurikulum 2013." Madrasah: Jurnal Pendidikan dan Pembelajaran Dasar 12, no. 1 (2019): 1-13. https://doi.org/10.18860/mad.v12i1.7744.

Zulmi, Billah Nurlaili. "Bias Gender dalam Buku Tematik Siswa Kurikulum 2013 (Studi Semiotika Ketidaksetaraan Gender dalam Pendidikan)." Paradigma: Jurnal Online Mahasiswa S1 Sosiologi UNESA 5, no. 3 (2017): 253229. https://www.neliti.com/id/publications/253229/. 